\title{
Glucagon-like peptide-1 inhibits adipose tissue macrophage infiltration and inflammation in an obese mouse model of diabetes
}

\author{
Y.-S. Lee • M.-S. Park • J.-S. Choung • S.-S. Kim • \\ H.-H. Oh • C.-S. Choi • S.-Y. Ha • Y. Kang • Y. Kim • \\ H.-S. Jun
}

Received: 15 February 2012 / Accepted: 24 April 2012 / Published online: 22 June 2012

(C) Springer-Verlag 2012

\begin{abstract}
Aims/hypothesis Obesity and insulin resistance are associated with low-grade chronic inflammation. Glucagon-like peptide-1 (GLP-1) is known to reduce insulin resistance. We investigated whether GLP-1 has anti-inflammatory effects on adipose tissue, including adipocytes and adipose tissue macrophages (ATM).

Methods We administered a recombinant adenovirus (rAd) producing GLP-1 (rAd-GLP-1) to an $o b / o b$ mouse model of diabetes. We examined insulin sensitivity, body fat mass, the
\end{abstract}

Electronic supplementary material The online version of this article (doi:10.1007/s00125-012-2592-3) contains peer-reviewed but unedited supplementary material, which is available to authorised users.

Y.-S. Lee • M.-S. Park • S.-S. Kim • H.-H. Oh • C.-S. Choi •

H.-S. Jun $(\bowtie)$

Lee Gil Ya Cancer and Diabetes Institute,

Gachon University,

7-45 Songdo-dong, Yeonsu-ku,

Incheon 406-840, South Korea

e-mail: hsjun@gachon.ac.kr

J.-S. Choung $\cdot$ H.-S. Jun

College of Pharmacy, Gachon University,

Incheon, South Korea

S.-Y. Ha

Department of Pathology, Gachon University Gil Hospital,

Incheon, South Korea

Y. Kang

Institute for Medical Sciences,

Ajou University School of Medicine,

Kyunggi-do, South Korea

Y. Kim

Department of Biomedical Sciences,

Seoul National University College of Medicine,

Seoul, South Korea infiltration of ATM and metabolic profiles. We analysed the mRNA expression of inflammatory cytokines, lipogenic genes, and M1 and M2 macrophage-specific genes in adipose tissue by real-time quantitative PCR. We also examined the activation of nuclear factor $\mathrm{\kappa B}(\mathrm{NF}-\mathrm{\kappa B})$, extracellular signalregulated kinase $1 / 2$ and Jun $\mathrm{N}$-terminal kinase (JNK) in vivo and in vitro.

Results Fat mass, adipocyte size and mRNA expression of lipogenic genes were significantly reduced in adipose tissue of rAd-GLP-1-treated $o b / o b$ mice. Macrophage populations (F4/80 $0^{+}$and $\mathrm{F} 4 / 80^{+} \mathrm{CD} 11 \mathrm{~b}^{+} \mathrm{CD} 11 \mathrm{c}^{+}$cells), as well as the expression and production of IL-6, TNF- $\alpha$ and monocyte chemoattractant protein-1, were significantly reduced in adipose tissue of rAd-GLP-1-treated $o b / o b$ mice. Expression of M1-specific mRNAs was significantly reduced, but that of M2-specific mRNAs was unchanged in rAd-GLP-1-treated $o b / o b$ mice. NF-KB and JNK activation was significantly reduced in adipose tissue of rAd-GLP-1-treated $o b / o b$ mice. Lipopolysaccharide-induced inflammation was reduced by the GLP-1 receptor agonist, exendin-4, in 3T3-L1 adipocytes and ATM.

Conclusions/interpretation We suggest that GLP-1 reduces macrophage infiltration and directly inhibits inflammatory pathways in adipocytes and ATM, possibly contributing to the improvement of insulin sensitivity.

Keywords Adipose tissue - Adipose tissue macrophage · Anti-inflammatory · Cytokine · Glucagon-like peptide-1 . Inflammatory signalling $\cdot$ Insulin resistance $\cdot$ Lipogenic genes $\cdot$ M1 $\cdot$ M2 macrophage
Abbreviations
ATM
Adipose tissue macrophages
EMSA 


$\begin{array}{ll}\text { ERK 1/2 } & \text { Extracellular signal-regulated kinase 1/2 } \\ \text { GLP-1 } & \text { Glucagon-like peptide-1 } \\ \text { JNK } & \text { Jun N-terminal kinase } \\ \text { LPS } & \text { Lipopolysaccharide } \\ \text { MCP } & \text { Monocyte chemoattractant protein } \\ \text { NF-kB } & \text { Nuclear factor } \kappa B \\ \text { rAd } & \text { Recombinant adenovirus } \\ \text { rAd- } \beta \text { gal } & \text { rAd producing } \beta \text {-galactosidase } \\ \text { rAd-GLP-1 } & \text { rAd producing GLP-1 } \\ \dot{V} \mathrm{O}_{2} & \text { Oxygen consumption }\end{array}$

\section{Introduction}

Obesity is associated with chronic, low-grade inflammation in adipose tissue, which contributes to the development of insulin resistance, a major cause of the metabolic syndrome, including type 2 diabetes [1]. The abundance of inflammatory cytokines, e.g. IL- 6 and TNF- $\alpha$, and chemokines is increased in fat cells of obese patients [2] and is correlated with insulin resistance [1]. Increased macrophage and $T$ cell infiltration is observed in adipose tissue in obesity, and macrophages alter the levels of insulin signalling molecules and GLUT4, as well as inhibiting insulin action in adipocytes [3]. There is considerable evidence in support of the hypothesis that inflammation and immune cells play an important role in metabolic dysregulation. The inhibition of inflammatory signalling pathways or blocking of immune cell recruitment is correlated with improved insulin sensitivity. Myeloid-specific $I k b k b$ knockout mice (in which the gene encoding inhibitor of $\mathrm{KB}$ kinase $\beta$ has been knocked out) are spared from obesity-induced insulin resistance [4]. Mcp 1 knockout or Ccr2 knockout mice (in which the genes encoding monocyte chemoattractant protein [MCP]-1 and chemokine [C-C motif] receptor 2, respectively, have been knocked out) show reduced levels of adipose tissue macrophages (ATM) and are protected from obesity-induced insulin resistance [5, 6]. Treatment with anti-CD3 antibody to deplete T cells reduces Th1 cells and reverses insulin resistance [7].

Glucagon-like peptide-1 (GLP-1), which is secreted from intestinal L-cells in response to nutrient ingestion, is known to have many glucose-lowering actions, potentiating glucose-dependent insulin secretion, enhancing beta cell growth, and reducing food intake and body weight $[8,9]$. In addition, GLP-1 improves insulin sensitivity in type 2 diabetic patients and animal models of the disease [10-12]. Further studies on mechanisms by which GLP-1 improves insulin sensitivity have shown that treatment of 3T3-L1 adipocytes with exendin-4, a GLP-1 receptor agonist, increases insulin-stimulated glucose uptake [13] and amplifies insulin signalling by upregulating basal insulin receptor, IRS-1 and GLUT4 abundance [14]. It has also been reported that exendin-4 increases adiponectin levels and prevents inflammatory adipokine production in 3T3-L1 adipocytes [15]. However, it is not known whether GLP-1 plays any role in adipose tissue inflammation, including ATM.

We have previously found that GLP-1 therapy improved insulin sensitivity, increased the activation of insulin signalling molecules in peripheral tissue and remitted diabetes in an obese mouse model of diabetes [10]. As obesity is associated with macrophage infiltration and inflammatory responses in adipose tissue that affect the development of insulin resistance, we investigated the role of GLP-1 in adipose tissue inflammation and macrophage infiltration. We show that GLP-1 reduces infiltration of ATM and has direct anti-inflammatory effects on adipocytes and ATM.

\section{Methods}

Animals Mice obtained from the Korea Research Institute of Bioscience and Biotechnology (Daejeon, Korea) were maintained at a facility at Gachon University. All animal experiments were carried out under a protocol approved by the Institutional Animal Care and Use Committee at Lee Gil Ya Cancer and Diabetes Institute, Gachon University.

Production of recombinant adenovirus producing GLP-1 (7-37) and treatment of ob/ob mice Recombinant adenovirus (rAd) producing GLP-1 (rAd-GLP-1) or rAd producing $\beta$-galactosidase (rAd- $\beta$ gal) were produced as previously described [10]. Diabetic male ob/ob mice (blood glucose levels $>13.9 \mathrm{mmol} / 1$ [ $[250 \mathrm{mg} / \mathrm{dl}]$ for three consecutive days) were injected at 6 to 8 weeks of age with rAd-GLP-1 or rAd$\beta$ gal $\left(4 \times 10^{9}\right.$ plaque-forming units, i.v.). Intravenous injection of rAd-GLP-1 produces GLP-1 mainly in liver. Pair-fed and $\mathrm{rAd}-\beta$ gal-treated pair-fed control mice were given the same daily amount of food as that eaten by the corresponding rAd-GLP-1-treated group during the previous day. All animal groups were matched for body weight with the rAd-GLP-1-treated group at the beginning of each experiment.

Histological staining of adipose tissue and measurement of adipocyte size and number Quantitative evaluation of adipocyte size and number was performed on haematoxylin and eosin-stained sections using the UTHSCSA Image Tool program (http://compdent.uthscsa.edu).

Isolation of stromal vascular cells and flow cytometric analysis Stromal vascular cells were isolated from epididymal adipose tissue and stained with fluorescein isothiocyanateconjugated anti-mouse F4/80 antibody, allophycocyaninconjugated anti-mouse $\mathrm{CD} 11 \mathrm{c}$ antibody and/or peridinin chlorophyll protein-conjugated anti-mouse $\mathrm{CD} 11 \mathrm{~b}$ antibody 
(eBioscience, San Diego, CA, USA). Cells were analysed on a FACSCalibur (BD Bioscience, San Jose, CA, USA) with CellQuest software (BD Bioscience).

3T3-L1 cell differentiation and treatment 3T3-L1 preadipocytes were cultured and induced to differentiate as described previously $[16,17]$.

Real-time quantitative PCR PCR was carried out in a PCR system (7900HT fast real-time PCR; Applied Biosystems, Carlsbad, CA, USA). The PCR primers used are shown in Electronic Supplementary Material (ESM) Table 1. The relative copy number was calculated using the threshold crossing point $\left(\mathrm{C}_{\mathrm{t}}\right)$ as calculated by the system's software, combined with the $2^{-\Delta \Delta \mathrm{C}_{\mathrm{t}}}$ calculations.

Western blot Western blots were performed with anti-AKT, anti-phospho-AKT (Ser473), anti-extracellular signalregulated kinase (ERK)1/2, anti-phospho-ERK1/2 and antiphospho-Jun N-terminal kinase (JNK) (Cell Signaling Technology, Beverly, MA, USA), and with anti-NF-kB p65 or antilamin B (Santa Cruz Biotechnology, Santa Cruz, CA, USA).

Electrophoretic mobility shift assay We performed electrophoretic mobility shift assay (EMSA) as described previously [18] using oligonucleotides for a specific NF-KB binding site (5'-AGTTGAGGGGACTTTCCCAGGC-3').

Isolation of $\mathrm{CD} 11 b^{+}$macrophages Epididymal fat pads were excised from male C57BL/ 6 mice fed a high-fat diet (60\% fat; Research Diets, New Brunswick, NJ, USA) for 8 to 10 weeks. Stromal vascular cells were collected and $\mathrm{CD} 11 \mathrm{~b}^{+}$cells isolated by immunoaffinity isolation using anti-CD11b antibodies conjugated to magnetic beads (MACS; Milenyi Biotec, Auburn, CA, USA). Isolated $\mathrm{CD} 11 \mathrm{~b}^{+}$cells were allowed to attach to a plate for $2 \mathrm{~h}$ at $37^{\circ} \mathrm{C}$.

Measurement of $N F-\kappa B$ translocation ATMs were incubated with anti-NF-KB and DyLight 549-labelled goat antirabbit antibody (Thermo Scientific, Loughborough, UK). Fluorescent cell images were obtained on a confocal laser scanning microscope (LSM 700; Carl Zeiss MicroImaging, Jena, Germany) and an HCS reader (ArrayScan), and effective image analysis was done using Cellomics Technologies software (Thermo Scientific).

Energy balance A comprehensive animal metabolic monitoring system (CLAMS; Columbus Instruments, Columbus, OH, USA) was used for $72 \mathrm{~h}$ at 3 days after rAd-GLP-1 or rAd- $\beta$ gal treatment. Energy expenditure and respiratory exchange ratios were calculated from gas exchange. The respiratory exchange ratio was computed as carbon dioxide output $\left(\dot{V} \mathrm{CO}_{2}\right)$ divided by oxygen consumption $\left(\dot{V} \mathrm{O}_{2}\right)$.
Activity was measured on the $x$ and $z$ axes by counting the breaks in an infrared beam during a measurement period.

Statistical analysis Data are presented as means $\pm \mathrm{SD}$ or means \pm SEM. The statistical significance of the difference between two groups was analysed by unpaired Student's $t$ test or ANOVA, followed by Tukey's honestly significant difference (HSD) test for multiple comparisons. A value of $p<0.05$ was accepted as significant.

\section{Results}

Improvement of insulin sensitivity and reduction of fat mass by rAd-GLP-1 treatment in diabetic ob/ob mice We had previously found that rAd-GLP-1 injection into diabetic $o b / o b$ mice normalised blood glucose levels and improved insulin sensitivity [10]. To confirm these previous findings of a glucose-lowering effect of rAd-GLP-1, we injected rAd-GLP-1 $\left(4 \times 10^{9}\right.$ plaque-forming units $)$ into the tail vein of diabetic $o b / o b$ mice. We found that glucose levels decreased, GLP-1 was produced, insulin levels decreased, and glucose and insulin tolerance improved at 2 weeks after the rAd-GLP-1 injection (ESM Fig. 1), a finding consistent with our previous results [10].

Food intake in rAd-GLP-1-treated mice rapidly decreased and remained significantly lower than in the rAd$\beta$ gal-treated group over the 10 days of the experiment (ESM Fig. 2a). The rAd-GLP-1-treated, pair-fed and rAd- $\beta$ galtreated+pair-fed groups had reduced body weights compared with the group treated with rAd- $\beta$ gal only (ESM Fig. 2b). We looked for differences in changes of fat mass between the rAd-GLP-1-treated and the pair-fed group. Analysis of fat mass by the ${ }^{1} \mathrm{H}$ minispec system showed that fat mass as a proportion of body weight was significantly reduced in rAd-GLP-1-treated $o b / o b$ mice compared with untreated and rAd- $\beta$ gal-treated $o b / o b$ mice, but was not reduced in the pair-fed group (ESM Fig. 2c). To determine whether rAd-GLP-1 treatment reduces fat at specific sites, we measured the weight of epididymal, mesenteric, perirenal and subcutaneous fat of mice at 2 weeks after rAdGLP-1 treatment. The weights of the first three were significantly reduced in rAd-GLP-1-treated $o b / o b$ mice compared with rAd- $\beta$ gal-treated mice, whereas subcutaneous fat in rAd-GLP-1-treated and pair-fed $o b / o b$ mice did not differ in weight from that in rAd- $\beta$ gal-treated mice. Mesenteric fat had a significantly reduced weight in the pair-fed group compared with the rAd- $\beta$ gal-treated group (ESM Table 2).

Reduction of adipocyte size and expression of lipogenic genes in rAd-GLP-1-treated ob/ob mice To determine whether rAd-GLP-1 treatment affects the size of adipocytes, we prepared sections of epididymal adipose tissue at 2 weeks 
after the rAd-GLP-1 injection, stained them with haematoxylin and eosin (Fig. 1a), and measured the adipocyte diameter and number. The size of adipocytes was significantly reduced (Fig. 1b) and the number of adipocytes in the same area was significantly increased (Fig. 1c) in rAd-GLP-1treated $o b / o b$ mice compared with untreated and rAd- $\beta$ galtreated mice. The size and number of adipocytes in the pairfed mice were similar to untreated and $\mathrm{rAd}-\beta$ gal-treated mice. To investigate de novo lipogenesis in rAd-GLP-1treated mice, we measured the mRNA expression of Srebplc (also known as Srebfl), Accl (also known as Acaca) and Fas (also known as Fasn), all genes that are involved in lipogenesis. We found that mRNA expression for these genes was significantly decreased in epididymal adipose tissue at 2 weeks after rAd-GLP-1 treatment (Fig. 1d-f). To investigate whether GLP-1 receptor stimulation directly affects lipogenesis and lipogenic gene expression, we treated 3T3-L1 pre-adipocytes with exendin-4 during differentiation and maturation, and examined triacylglycerol accumulation and mRNA levels of lipogenic genes. In contrast to the in vivo results, we found that triacylglycerol accumulation and the expression of Srebplc and Fas
mRNA were significantly increased in exendin-4-treated 3T3-L1 adipocytes (ESM Fig. 3).

Decreased macrophage infiltration and reduced MI macrophage-specific mRNA expression in adipose tissue of rAd-GLP-1-treated mice To determine whether macrophage infiltration in white adipose tissue was changed by rAdGLP-1 treatment, we analysed the $\mathrm{F} 4 / 80^{+}$macrophage population in the stromal vascular fraction from epididymal fat by flow cytometric analysis at 2 weeks after treatment. The number of infiltrated cells was significantly decreased in epididymal fat of rAd-GLP-1-treated mice (Fig. 2a). The $\mathrm{F} 4 / 80^{+}$macrophage population was also significantly decreased in rAd-GLP-1-treated mice compared with rAd$\beta$ gal-treated mice (Fig. 2b, c). As F $4 / 80^{+} \mathrm{CD} 11 \mathrm{~b}^{+} \mathrm{CD} 11 \mathrm{c}^{+}$ cells are known to be specific targets for NEFA and high-fat feeding [19], we analysed the $\mathrm{F} 4 / 80^{+} \mathrm{CD} 11 \mathrm{~b}^{+} \mathrm{CD} 11 \mathrm{c}^{+}$cell population and found that it was significantly decreased in rAd-GLP-1-treated mice compared with rAd- $\beta$ gal-treated mice (Fig. $2 \mathrm{~d}$, e). The $\mathrm{F} 4 / 80^{+} \mathrm{CD} 11 \mathrm{~b}^{+} \mathrm{CD} 11 \mathrm{c}^{-}$cell population was also significantly reduced in rAd-GLP-1-treated mice (Fig. 2f). Based on these results, we examined the a

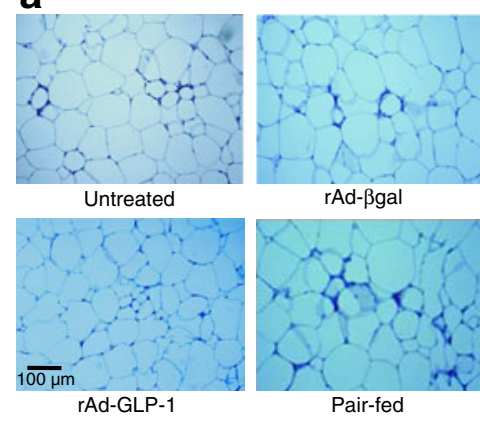

b

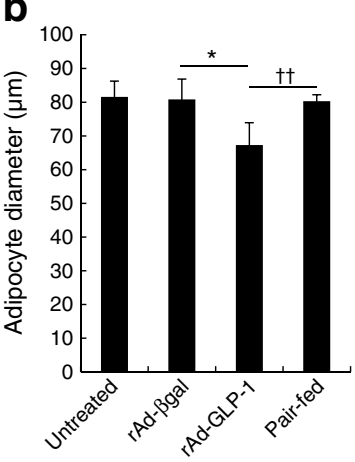

C

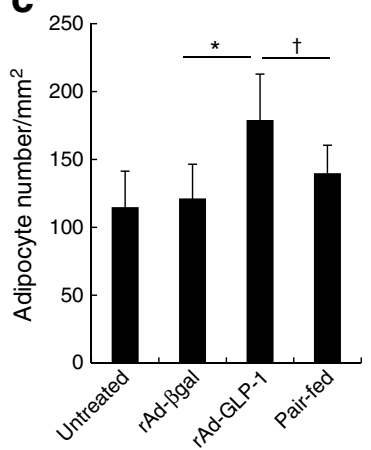

d

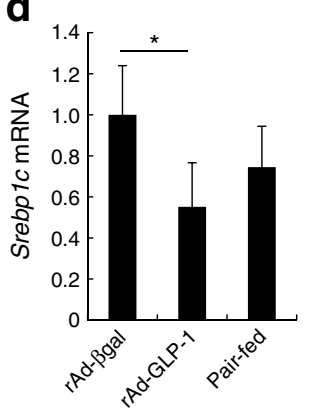

e

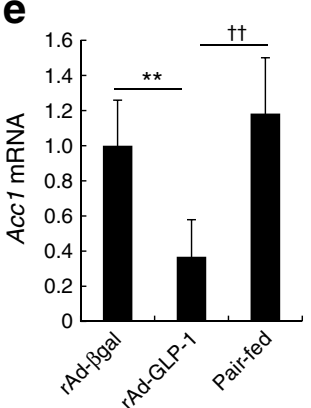

f

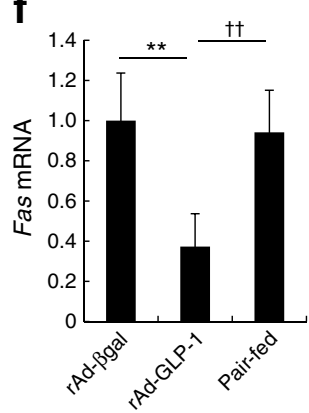

Fig. 1 Changes in adipocyte size and number, and expression of lipogenic genes in epididymal fat of rAd-GLP-1-treated $o b / o b$ mice. Diabetic $o b / o b$ mice were treated with rAd-GLP-1 or rAd- $\beta$ gal and sections of epididymal adipose tissues prepared and stained as described in Methods. (a) Representative photomicrograph (magnification $\times 200$ ). (b) The adipocyte diameter and (c) numbers of cells in the same area were measured with an image tool program (UTHSCSA); $n=3-4$ per group. Untreated and pair-fed diabetic $o b / o b$ mice served as controls. (d) The expression of Srebplc, (e) Accl and (f) FAS mRNA in epididymal fat was analysed by real-time quantitative PCR and normalised to cyclophilin mRNA expression. The fold change was calculated as ratio of the expression level in rAd- $\beta$ gal-treated mice; $n=3-9$ per group. Pair-fed diabetic $o b / o b$ mice served as controls. Data $(\mathbf{b}-\mathbf{f})$ are means $\pm \mathrm{SD} ;{ }^{*} p<0.05$ and ${ }^{*} p<0.01$ compared with rAd- $\beta$ galtreated mice; ${ }^{\dagger} p<0.05$ and ${ }^{\dagger \dagger} p<0.01$ compared with the pair-fed group 
a
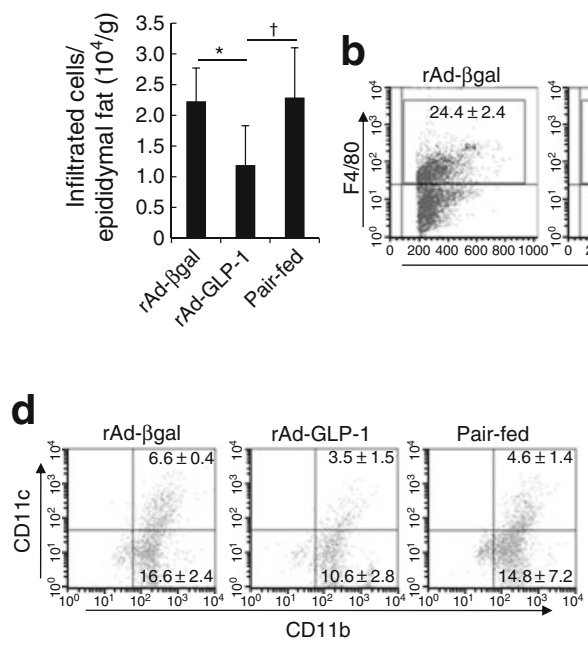

g

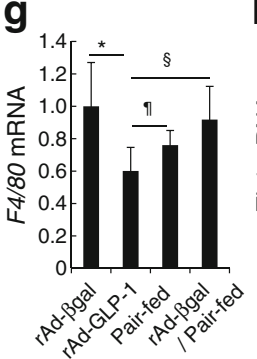

b

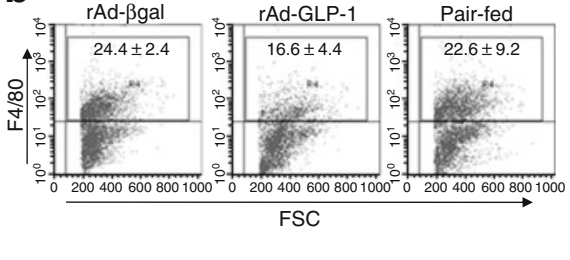

C

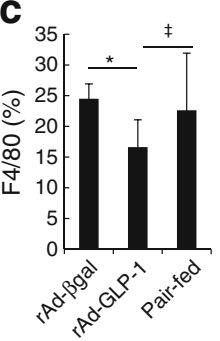

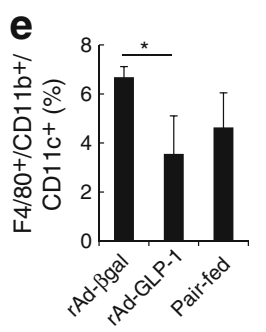
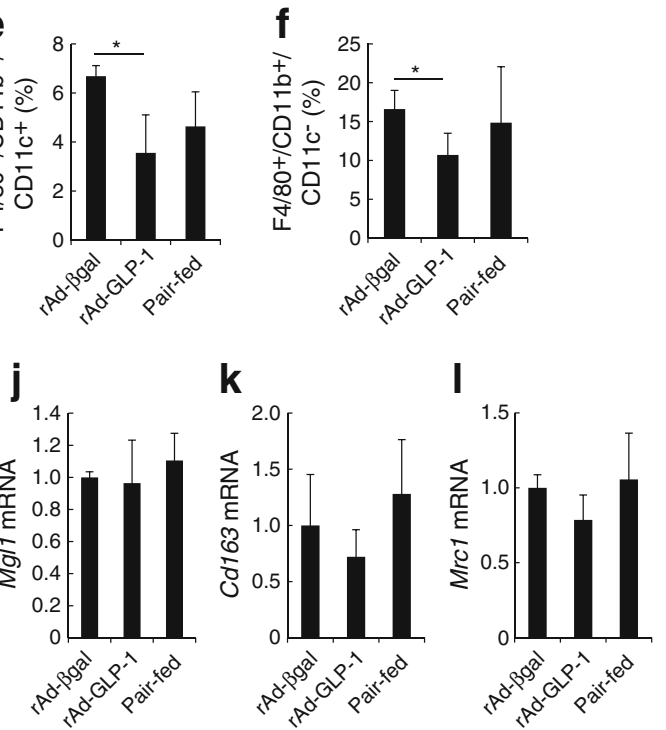

At 2 weeks after treatment, epididymal fat tissue was removed and the expression of F4/80, (h) Tlr4, (i) $\mathrm{Arg} 1$, (j) $\mathrm{Mgll}$, (k) Cd163 and (l) Mrcl mRNA was analysed by real-time quantitative PCR, with values normalised to cyclophilin expression. The fold change was calculated as ratio of the expression level in rAd- $\beta$ gal-treated mice; $n=3-6$ per group. Pair-fed diabetic $o b / o b$ mice served as controls. Data are means $\pm \mathrm{SD} ;{ }^{*} p<0.05$ compared with $\mathrm{rAd}-\beta$ gal-treated mice; ${ }^{\dagger} p<0.05$ and

${ }^{\dagger \dagger} p<0.01$ compared with the pair-fed group; ${ }^{\S} p=0.06 ; " ⿱ 一 ⿻ 上 丨=0.09$

GLP-1-treated mice. Real-time quantitative PCR analysis of the expression of Il6, Tnfa (also known as Tnf) and Mcpl (also known as $C c l 2$ ) mRNA in adipose tissue showed, as expected, that the transcripts of these molecules were significantly decreased in rAd-GLP-1-treated mice compared with rAd- $\beta$ gal-treated mice (Fig. $3 \mathrm{a}-\mathrm{c}$ ). The production of IL-6, TNF- $\alpha$ and MCP-1 protein in adipose tissue was also significantly decreased in rAd-GLP-1-treated mice (Fig. 3d-f). There were no significant differences in inflammatory cytokine mRNA or protein abundance (except IL-6) between the rAd$\beta$ gal-treated, pair-fed, and rAd- $\beta$ gal-treated + pair-fed groups (Fig. 3a-f). Examination of the expression of Tnfa, Tlr4 and Mcp 1 mRNA in peritoneal macrophages at 2 weeks after rAd-GLP-1 treatment showed that the corresponding molecules were significantly decreased in rAd-GLP-1-treated $o b / o b$ mice compared with rAd- $\beta$ gal-treated mice (Fig. $3 \mathrm{~g}-\mathrm{j}$ ). Il6 mRNA expression was also decreased, but this was not 
Fig. 3 Decrease of inflammatory cytokine mRNA expression and production in adipose tissue and peritoneal macrophages of rAd-GLP-1treated $o b / o b$ mice. Diabetic $o b / o b$ mice were treated with rAd-GLP-1 or rAd- $\beta$ gal and epididymal fat was removed as indicated in the Methods.

(a) The expression of Il6, (b)

Tnfa and (c) Mcp 1 mRNA, and protein levels of (d) IL-6,

(e) TNF- $\alpha$ and (f) MCP-1 were measured ( $n=5-13$ per group). Untreated and pair-fed diabetic $o b / o b$ mice served as controls. For mRNA measurement, the fold change was calculated as the ratio of the expression in rAd- $\beta$ gal-treated mice.

(g) Peritoneal macrophages were isolated from diabetic $o b /$ $o b$ mice at 2 weeks after rAdGLP-1 treatment, and Il6, (h) Tnfa, (i) Tlr4 and (j) Mcp 1 mRNA was analysed as described above. Untreated mice served as controls. Data are means $\pm \mathrm{SD} ;{ }^{*} p<0.05,{ }^{* *} p<$ 0.005 and $* * * p<0.001$ compared with rAd- $\beta$ gal-treated $o b /$ $o b$ mice; ${ }^{\dagger} p<0.05$ compared with pair-fed group a

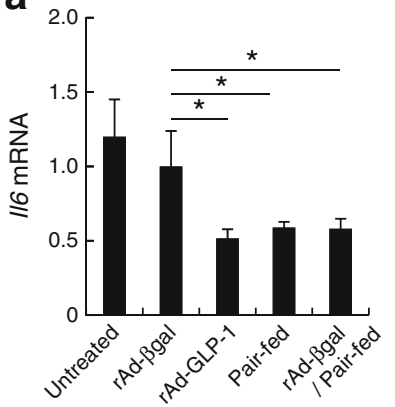

d

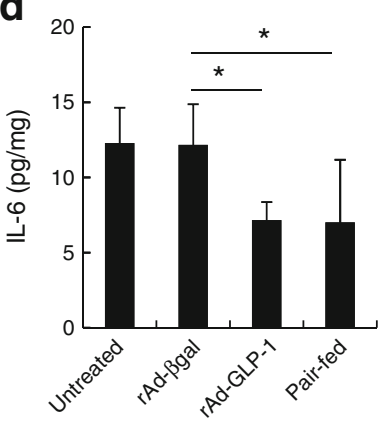

g

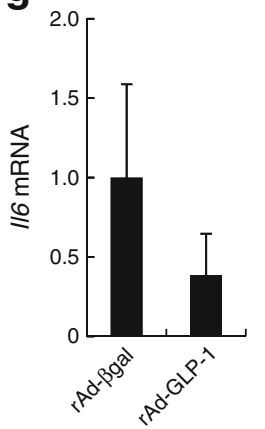

b

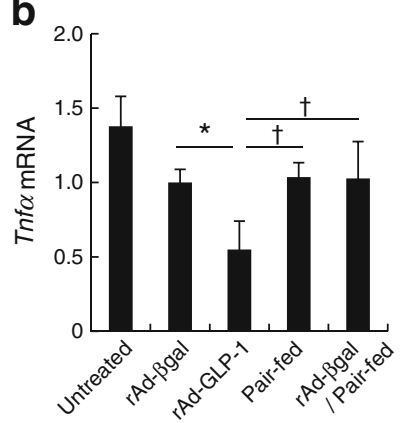

e

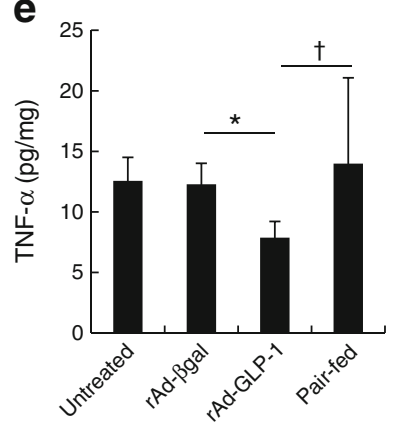

C

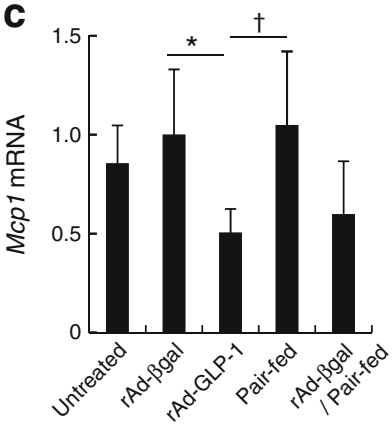

f

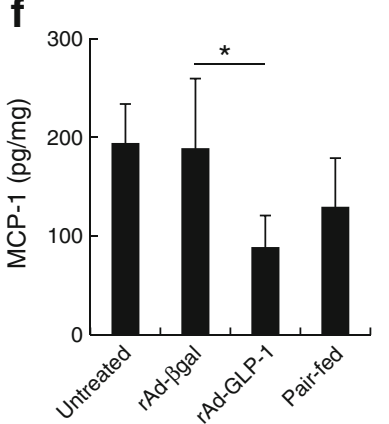

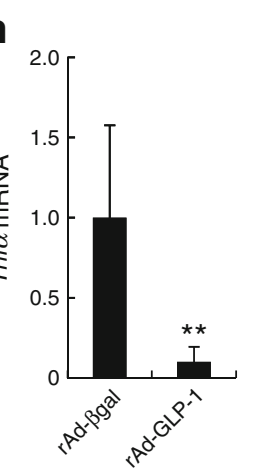
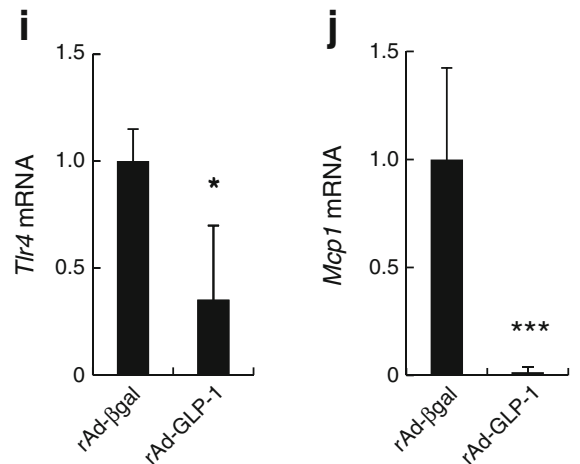

statistically significant (Fig. 3g). The serum concentrations of TNF- $\alpha$ and MCP-1 were not statistically different between treatments (ESM Fig. 4).

\section{Reduction of NF- $\kappa B, E R K 1 / 2$ and JNK activation in adipose} tissue of rAd-GLP-1-treated mice Activation of NF- $\mathrm{kB}$ is involved mainly in the expression of inflammatory responsive genes such as $I l 6$ and Tnfa [20, 21]. As pro-inflammatory cytokine production is reduced by rAd-GLP-1 treatment, we used EMSA to examine the activation of NF- $\mathrm{KB}$ in epididymal fat at 2 weeks after rAd-GLP-1 treatment. We found that NF- $\mathrm{KB}$ binding activity was reduced in adipose tissue of rAdGLP-1-treated $o b / o b$ mice compared with untreated, rAd$\beta$ gal-treated and pair-fed $o b / o b$ mice (Fig. 4a). Because ERK1/2 and JNK are involved in NF-KB activation [21-23], we examined the activation of ERK1/2 and JNK in epididymal fat by western blot. We found that phosphorylation of ERK1/2 and JNK was decreased in rAd-GLP-1-treated $o b / o b$ mice compared with untreated, rAd- $\beta$ gal-treated and pair-fed ob/ob mice (Fig. 4b).

In vitro and in vivo inhibition of lipopolysaccharide-induced $I L-6$ and TNF- $\alpha$ production by exendin- 4 To investigate whether GLP-1 receptor signalling directly inhibits proinflammatory cytokine mRNA expression in adipocytes, we pretreated differentiated 3T3-L1 adipocytes with exendin-4, stimulated them with lipopolysaccharide (LPS) and examined the expression of Il6 and Tnfa mRNA. When 3T3-L1 adipocytes were stimulated with LPS alone, the expression of $I l 6 \mathrm{mRNA}$ was elevated at 2, 4 and $6 \mathrm{~h}$ after stimulation; that of Tnfa mRNA was elevated at $2 \mathrm{~h}$ after stimulation. However, when adipocytes were pretreated with exendin-4 before LPS stimulation, the expression of the genes encoding these cytokines was significantly reduced (Fig. 5a-b). Examination of IL-6 and TNF- $\alpha$ secretion in the culture medium at $12 \mathrm{~h}$ or $24 \mathrm{~h}$ after LPS stimulation revealed 


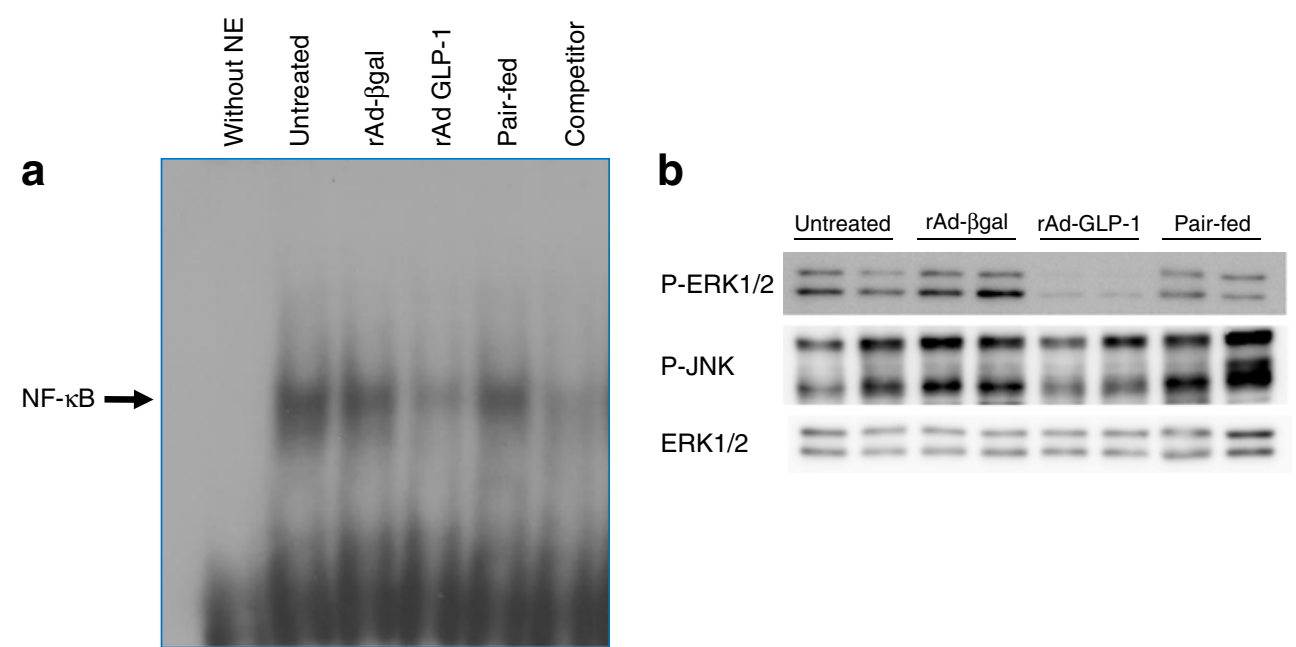

Fig. 4 rAd-GLP-1 treatment reduced NF- $k B$ activation and phosphorylation of ERK1/2 and JNK in epididymal fat tissue. Diabetic $o b / o b$ mice were treated with rAd-GLP-1 or rAd- $\beta$ gal and epididymal fat was removed 2 weeks after treatment. (a) Autoradiograph of EMSA performed with ${ }^{32} \mathrm{P}$-labelled NF- $\mathrm{kB}$ binding nucleotides and nuclear protein extracts (NE) of epididymal fat tissues from the indicated groups.

that exendin-4 treatment inhibited LPS-induced IL-6 (12 h) and TNF- $\alpha(24 \mathrm{~h})$ secretion compared with 3T3-L1 adipocyte cells treated with LPS alone (Fig. 5c-d). To confirm the in vitro effect of exendin-4 on the inhibition of LPS-induced inflammatory cytokine expression in vivo, we intraperitoneally injected C57BL/6 male mice with exendin-4 twice per day for 7 days, and then on day 7 injected mice with LPS. At $6 \mathrm{~h}$ after the LPS injection, the expression of $I l 6$ and Tnfa mRNA in adipose tissue was significantly suppressed by exendin-4 treatment compared with mice injected with LPS alone (Fig. 5e-f).

Inhibition of LPS-induced NF- $\kappa B$ activation by exendin-4 in 3T3-L1 adipocytes To determine whether the inhibition of LPS-induced $I l 6$ and Tnfa mRNA expression by exendin-4 was due to the inhibition of NF-KB activation, we used western blot to examine the LPS-induced translocation of NF-KB to the nucleus in exendin-4-treated 3T3-L1 adipocytes. We found that LPS-induced NF-kB/p65 nuclear translocation was suppressed by exendin-4 treatment (Fig. 6a). In addition, NF- $\mathrm{kB}$ DNA-binding activity was analysed by EMSA. The addition of excess unlabelled NF- $\mathrm{kB}$ oligonucleotide abolished NF- $\mathrm{KB}$ binding activity. Moreover, the addition of an antibody against the $\mathrm{p} 65$ subunit of NF- $\mathrm{KB}$ resulted in a supershift, indicating the specificity of the binding activity (Fig. 6b). We found that NF-KB binding activity was inhibited by exendin-4 treatment in 3T3-L1 adipocytes (Fig. 6c). ERK1/2 and phosphatidylinositol 3-kinase (PI3-K)/AKT are involved in LPS-induced NF$\mathrm{KB}$ activation [22-24]. We therefore examined the effect of exendin- 4 on LPS-induced activation of ERK1/2 and
Nuclear extracts from untreated mice incubated with an excess of the unlabelled probe (Competitor) served as a control. (b) Phospho(P)ERK1/2 and phospho-JNK, as well as ERK1/2 were measured by immunoblotting of total protein extracts with respective antibodies. Untreated and pair-fed diabetic $o b / o b$ mice served as controls. Results are representative of three independent experiments

AKT in adipocytes. We found that LPS induced a notable phosphorylation of ERK1/2 and AKT at 10 min after treatment, and that exendin- 4 treatment inhibited the LPSinduced phosphorylation of ERK1/2 and AKT in 3T3-L1 adipocytes (Fig. 6d).

Inhibition of inflammatory cytokine gene expression and $N F-\kappa B$ activation in exendin-4-treated ATM To investigate whether GLP-1 receptor signalling directly inhibits proinflammatory cytokine mRNA expression in ATM, we intraperitoneally injected exendin-4 into high-fat diet-induced obese mice, isolated $\mathrm{CD} 11 \mathrm{~b}^{+}$ATM from the epididymal fat $24 \mathrm{~h}$ later and examined the expression of Il6, Tnfa and Mcp1 mRNA. We found that the mRNA expression of these cytokines was significantly reduced in exendin-4-treated mice (Fig. 7a-c). In addition, we isolated CD11 $\mathrm{b}^{+}$ATM from the epididymal fat of obese mice, treated them with exendin-4 with or without LPS stimulation, and examined the expression of Il6, Tnfa and Mcpl mRNA. The expression of these mRNAs was significantly suppressed by exendin-4 treatment (Fig. 7d-i). Consistent with this result, LPS-induced NF-kB/p65 nuclear translocation was significantly inhibited by exendin- 4 treatment (Fig. $7 \mathrm{j}, \mathrm{k}$ ).

Maintenance of a high level of energy expenditure in rAdGLP-1-treated mice To investigate whether the reduction of fat mass is due to metabolic change induced by the rAdGLP-1 treatment, we measured food intake, energy expenditure, locomotor activity, oxygen consumption and the respiratory exchange ratio. This was done with a metabolic monitoring system over $72 \mathrm{~h}$, beginning 3 days after rAd- 

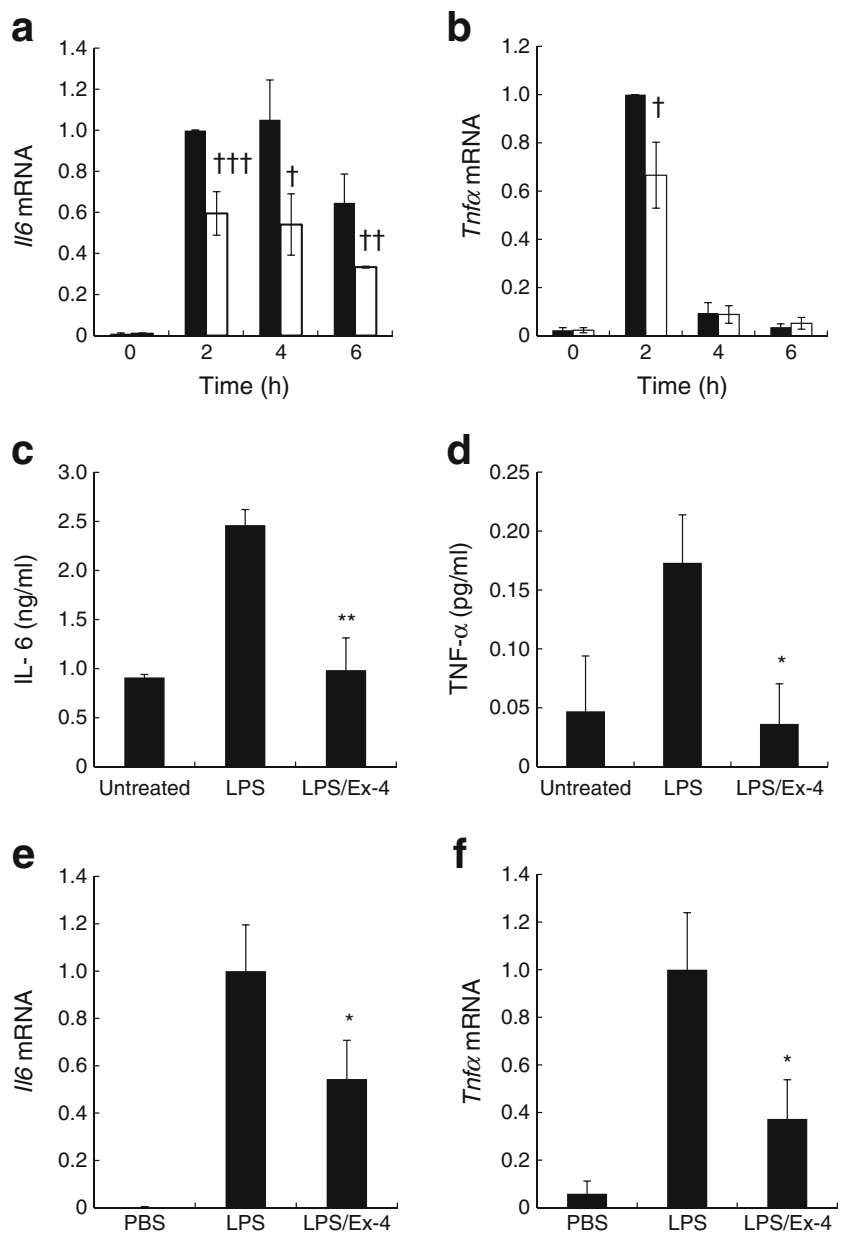

Fig. 5 Exendin-4 suppressed LPS-induced Il6 and Tnfa mRNA expression and protein production in 3T3-L1 adipocytes and C57BL/6 mice. (a) 3T3-L1 adipocytes were incubated with (white bars) or without (black bars) $20 \mathrm{nmol} / 1$ exendin-4 (Ex-4) for $24 \mathrm{~h}$, followed by treatment with LPS $(100 \mathrm{ng} / \mathrm{ml})$ for $0,2,4$ or $6 \mathrm{~h}$, and the expression of Il6 and (b) Tnfa mRNA was analysed by real-time quantitative PCR, with values normalised to cyclophilin expression. The fold change was calculated as ratio of the expression in cells treated with LPS only for 2 h. ${ }^{\dagger} p<0.005,{ }^{\dagger \dagger} p<0.0005$ and ${ }^{\dagger \dagger} p<0.0001$ compared with cells treated with LPS only. (c) Cell culture medium was collected at 12 or $24 \mathrm{~h}$ after LPS stimulation and the concentration of IL-6 and (d) TNF$\alpha$ was determined by ELISA. (e) Male C57BL/6 mice were injected intraperitoneally twice a day for 7 days with exendin-4 (100 ng/ mouse). As a control, the same volume of PBS was injected. At day 7 , mice were injected with LPS $(100 \mu \mathrm{g} /$ mouse $)$ and epididymal adipose tissue removed after $6 \mathrm{~h}$. The expression of (e) Il6 and (f) Tnfa mRNA was analysed by real-time quantitative PCR and normalised to cyclophilin expression. The fold change was calculated as ratio of the expression in mice injected with LPS only. (a-f) Results are representative of three independent experiments. Data are means $\pm \mathrm{SD} ; n=5$ per group; $(\mathbf{c}-\mathbf{f}) * p<0.05$ and $* * p<0.01$ compared with cells treated with LPS only

GLP-1 treatment. As expected, food intake was significantly reduced in rAd-GLP-1-treated mice compared with the rAdßgal-treated group (Fig. 8a). Energy expenditure (Fig. 8b) and oxygen consumption (Fig. 8c) were not different in rAdGLP-1-treated mice compared with the rAd- $\beta$ gal-treated group, but showed a tendency to be higher than in the pair-fed group, in spite of the same energy intake. In addition, locomotor activity was significantly decreased in the rAd-GLP-1-treated group compared with the pair-fed group (Fig. 8d). The respiratory exchange ratio was significantly decreased in rAd-GLP-1-treated $o b / o b$ mice and the pair-fed group compared with rAd- $\beta$ gal-treated $o b / o b$ mice (Fig. 8e).

\section{Discussion}

Obesity is linked to insulin resistance. One possible mechanism is that adipose tissue is infiltrated with immune cells that promote inflammatory responses, contributing to the pathogenesis of insulin resistance [1]. Blocking inflammatory pathways improves insulin sensitivity in high-fat dietinduced obesity or genetically obese diabetic mice [4, 25-27]. GLP-1 is known to improve insulin sensitivity [10-12], therefore this study investigated whether the suppression of adipose tissue inflammation might be a mechanism by which GLP-1 reduces insulin resistance. As GLP-1 has a short half-life, we used an rAd to constitutively produce GLP-1 in vivo, a strategy that successfully improved glucose levels and insulin sensitivity in a mouse model of type 2 diabetes [10].

Insulin resistance was significantly reduced in rAd-GLP-1treated $o b / o b$ mice compared with rAd- $\beta$ gal-treated or pairfed $o b / o b$ mice, confirming findings of our earlier study [10]. Although the rAd-GLP-1-treated and the pair-fed group (fed the same amount as that eaten by the rAd-GLP-1 group) had reduced body weight gain, only the rAd-GLP-1 group had a significant reduction in the relative amount of fat, suggesting that GLP-1 specifically reduces fat accumulation. Furthermore, rAd-GLP-1 treatment significantly reduced abdominal fat, but not subcutaneous fat, consistent with previous results showing that abdominal fat deposition is associated with insulin resistance [28, 29].

The size of adipocytes in epididymal fat of rAd-GLP-1treated $o b / o b$ mice was smaller than that in rAd- $\beta$ gal-treated and pair-fed $o b / o b$ mice, suggesting that lipogenesis might be reduced by rAd-GLP-1 treatment. As expected, the expression of lipogenic gene transcripts such as Srebplc, Accl and Fas mRNA was significantly decreased in adipose tissue of rAd-GLP-1-treated $o b / o b$ mice. However, exendin-4 treatment of 3T3-L1 adipocytes in vitro increased the expression of Srebplc and Fas mRNA, and increased triacylglycerol accumulation, similar to previous results where GLP-1 stimulated fatty acid synthesis in explants of rat adipose tissue [30] and lipogenesis in isolated rat adipocytes [31]. Therefore, the decrease of lipogenic gene expression in adipose tissue of rAd-GLP-1-treated mice might be due to indirect effects resulting from other factors, including reduced food intake. As the expression of these genes in the 

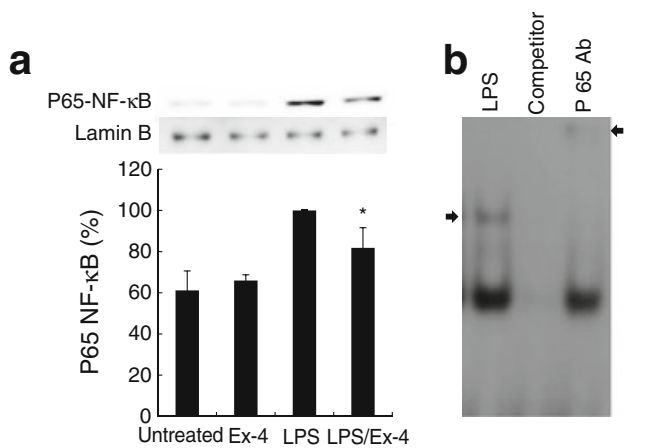

Fig. 6 Exendin-4 reduced LPS-induced NF-kB activation and phosphorylation of ERK1/2 and AKT in 3T3-L1 adipocytes. 3T3-L1 adipocytes were cultured for $24 \mathrm{~h}$ without (untreated) or with $20 \mathrm{nmol} / 1$ exendin- 4 (Ex-4), followed by treatment with LPS (100 $\mathrm{ng} / \mathrm{ml})$ for $1 \mathrm{~h}$ and preparation of nuclear extracts. (a) Western blot was performed with anti-NFKB p65 antibody or anti-lamin B protein. The p65 NF- $\mathrm{BB}$ band intensity was normalised to lamin B. Data are percentages of p65 NF- $\mathrm{kB}$ levels in 3T3-L1 adipocytes treated with LPS only and are presented as mean \pm $\mathrm{SD} ;{ }^{*} p<0.05$ compared with LPS-only treated cells. (b) Nuclear extracts from LPS-stimulated 3T3-L1 adipocytes were prepared and probed with ${ }^{32} \mathrm{P}$-labelled NF-KB after competition with a molar excess of an

pair-fed group, which showed reduced body weight gain similar to that of rAd-GLP-1-treated mice, was not significantly different from that in the rAd- $\beta$ gal-treated group, the reduction of lipogenic gene expression may not be simply due to the reduction of food intake. A recent report demonstrated that the inflammatory cytokine, TNF- $\alpha$, induced the expression of genes involved in lipid metabolism in HepG2 cells [32]. Thus, the inhibition of inflammatory cytokines may decrease the expression of lipogenic genes and reduce adiposity in rAd-GLP-1-treated mice. In addition, the normalisation of glucose and insulin levels by rAd-GLP-1 treatment [10] might also result in decreased expression of lipogenic genes and reduced adiposity, as glucose and insulin coordinately regulate de novo lipogenesis [33, 34].

Obesity is associated with low-grade systemic inflammation and increased levels of pro-inflammatory cytokines such as IL- 6 and TNF- $\alpha$ [2]. These cytokines are produced from adipocytes and ATM, contributing to insulin resistance $[35,36]$. Thus, we examined whether rAd-GLP-1-treatment reduces macrophage infiltration and pro-inflammatory cytokine production in adipose tissue. We found that the proportion of $\mathrm{F} 4 / 80^{+}$macrophages, as well as the mRNA expression and protein levels of IL- 6 , TNF- $\alpha$ and MCP-1, were significantly decreased in the adipose tissue of rAd-GLP-1-treated mice.

Recently, it has been shown that $\mathrm{F} 4 / 80^{+} \mathrm{CD} 11 \mathrm{~b}^{+} \mathrm{CD} 11 \mathrm{c}^{+}$ triply positive cells, which have macrophage and dendritic cell-like features, are increased in adipose tissue during obesity and produce increased levels of inflammatory cytokines compared with $\mathrm{F} 4 / 80^{+} \mathrm{CD} 11 \mathrm{~b}^{+} \mathrm{CD} 11 \mathrm{c}^{-}$cells [19]. It has also been reported that the ablation of $\mathrm{CD} 11 \mathrm{c}^{+}$cells

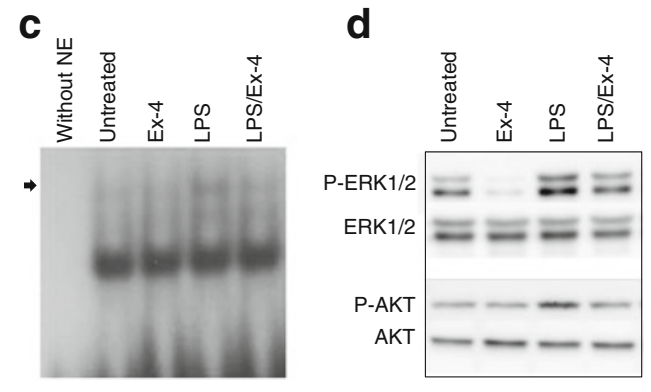

unlabelled probe (Competitor) or by incubation with an antibody against p65 NF- $\mathrm{BB}(\mathrm{P} 65 \mathrm{Ab})$. Arrow left, p65 NF-kB band; arrow right, supershifted band. (c) Autoradiogram of EMSA performed with nuclear extract (NE) of untreated, exendin-4-treated (20 nmol/1), LPS-treated $(100 \mathrm{ng} / \mathrm{ml}$, $1 \mathrm{~h}$ ), and exendin-4- (20 nmol/l) and LPS-treated (100 ng/ml, $1 \mathrm{~h}$ ) 3T3-L1 adipocytes. Arrow, p65 NF-kB band. (d) 3T3-L1 adipocytes were cultured without (untreated) or with exendin-4 (20 nmol/l) for $24 \mathrm{~h}$, followed by treatment with LPS $(100 \mathrm{ng} / \mathrm{ml})$ for $10 \mathrm{~min}$. Cell extracts were prepared and analysed by western blot using anti-ERK1/2 and antiphospho (P)-ERK1/2 antibodies, or anti-AKT and anti-phospho-AKT antibodies. Results are representative of three independent experiments

decreases the inflammatory condition and protects against high-fat diet-induced insulin resistance [37]. We found that rAd-GLP-1 treatment of diabetic $o b / o b$ mice significantly reduced this triply positive cell population, indicating that the reduced infiltration of triply positive cells contributes to the decrease of inflammatory cytokines by GLP-1.

Classically activated M1 macrophages produce inflammatory mediators, whereas alternatively activated M2 macrophages are generated by exposure to IL-4 and IL-13, and produce anti-inflammatory cytokines [38]. We found that the mRNA expression of M1 marker genes (F4/80 and Tlr4) was significantly decreased by rAd-GLP-1 treatment, whereas the expression of M2 marker genes ( $\mathrm{Arg} 1, \mathrm{Mgll}$, Cd163 and Mrcl) was not changed. These results suggest that GLP-1 may affect the production of inflammatory, rather than that of anti-inflammatory, molecules. We also found that exendin-4 inhibited the LPS-induced expression of inflammatory cytokine genes in 3T3-L1 adipocytes and ATM in vitro, and that the expression of Tnfa, Tlr4 and Mcp 1 mRNA was significantly reduced in peritoneal macrophages from rAd-GLP-1-treated $o b / o b$ mice compared with rAd- $\beta$ gal-treated mice. All of these results strongly support the hypothesis that GLP-1 inhibits the inflammatory pathways, possibly contributing to the improvement of insulin sensitivity.

The activation of NF-KB and JNK signalling pathways induces inflammatory cytokine and chemokine gene expression. Indeed, there is evidence that these pathways are linked to insulin resistance in type 2 diabetes. Hyperactivation of the NF-KB pathway has been reported in white adipose tissue from the Zucker diabetic fatty rat [22], an 

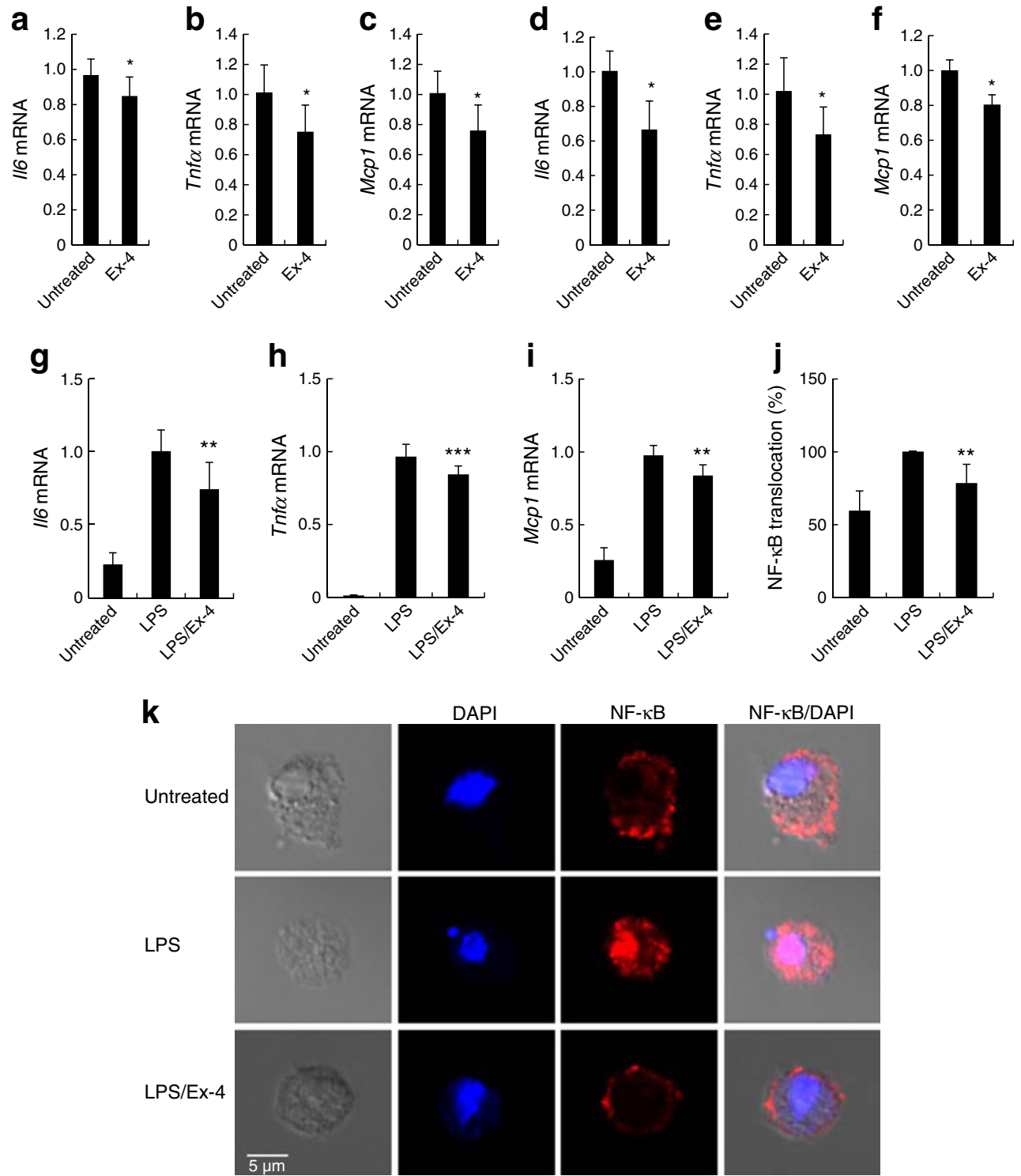

NF-KB/DAPI

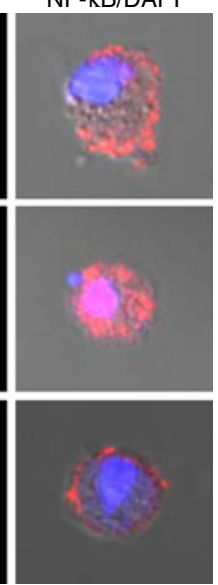

Fig. 7 Decrease of inflammatory cytokine gene expression and NF- $\mathrm{kB}$ activation in exendin-4-treated ATM. (a) C57BL/6 mice were fed a high-fat diet for 8 weeks and then injected with exendin-4 (Ex-4) $(100 \mathrm{ng} /$ mouse, twice at $12 \mathrm{~h}$ intervals). After $24 \mathrm{~h}$, ATM were isolated from epididymal fat pads and the expression of Il6, (b) Tnfa and (c) Mcp 1 mRNA was measured. (d) ATM isolated from epididymal fat pads of male C57BL/6 mice fed a high-fat diet for 8 weeks were cultured for $24 \mathrm{~h}$ with or without $0.3 \mathrm{nmol} / 1$ exendin- 4 and the expression of the pro-inflammatory cytokines (d) Il6, (e) Tnfa and (f) Mcpl was measured. (g) ATM were cultured for $24 \mathrm{~h}$ and then treated with

animal model of type 2 diabetes. JNK1-deficient and NFKB-deficient mice are protected from high-fat diet-induced insulin resistance $[39,40]$, due to the inhibition of inflammatory cytokine production $[41,42]$. We found that the activity of NF- $\mathrm{KB}$ was markedly reduced in adipose tissue of rAd-GLP-1-treated mice and that the LPS-induced activation of NF- $\mathrm{KB}$ was inhibited in 3T3-L1 adipocytes and ATM treated with exendin- 4 in vitro. This suggests that the normalisation of abnormally activated inflammatory
$0.3 \mathrm{nmol} / 1$ exendin- 4 for $1 \mathrm{~h}$, followed by treatment with LPS $(100 \mathrm{ng} / \mathrm{ml})$ for $1 \mathrm{~h}$, after which the expression of (g) Il6, (h) Tnfa and (i) Mcp 1 mRNA was analysed by real-time quantitative PCR. (j) NF-kB translocation was measured by ArrayScan HCS reader and (k) immunohistochemistry. Nuclei were stained with 4'-6-diamidino-2-phenylindole. The fold change $(\mathbf{g}-\mathbf{j})$ was calculated as ratio of the expression in LPS-only-treated groups. All results are representative of three independent experiments. Data $(\mathbf{a}-\mathbf{j})$ are means $\pm \mathrm{SD} ;{ }^{*} p<0.05,{ }^{* *} p<0.005$ and ${ }^{* * *} p<0.001$ compared with LPS only-treated groups

signalling by GLP-1 contributes to the decreased production of inflammatory cytokines and chemokines. Consistent with our results, it was recently reported that exendin-4 treatment showed anti-inflammatory effects on glomerular endothelial cells and macrophages [43], and that liraglutide, a longacting GLP-1 analogue, also inhibited NF- $\mathrm{KB}$ activation in human umbilical vein endothelial cells [44].

Energy intake in excess of energy expenditure may cause obesity and insulin resistance, while dysregulation of energy 
Fig. 8 Maintenance of a high level of energy expenditure in rAd-GLP-1-treated $o b / o b$ mice. Diabetic $o b / o b$ mice were treated with rAd-GLP-1 or rAd- $\beta$ gal. (a) Food intake, (b) energy expenditure (EE), (c) $\dot{V} \mathrm{O}_{2}$, (d) activity and (e) respiratory exchange ratio (RER) were measured by indirect calorimetry analysis for $72 \mathrm{~h}$, beginning at 3 days after rAdGLP-1 or rAd- $\beta$ gal treatment. Untreated mice served as controls. Data are means $\pm \mathrm{SEM}$; $n=7-8$ per group; $* p<0.05$, $* * p<0.01$ and $* * * p<0.0005$ compared with rAd- $\beta$ galtreated mice; ${ }^{\S} p<0.005$ compared with the pair-fed group; ${ }^{\dagger} p=0.103 ;{ }^{\ddagger} p=0.055$
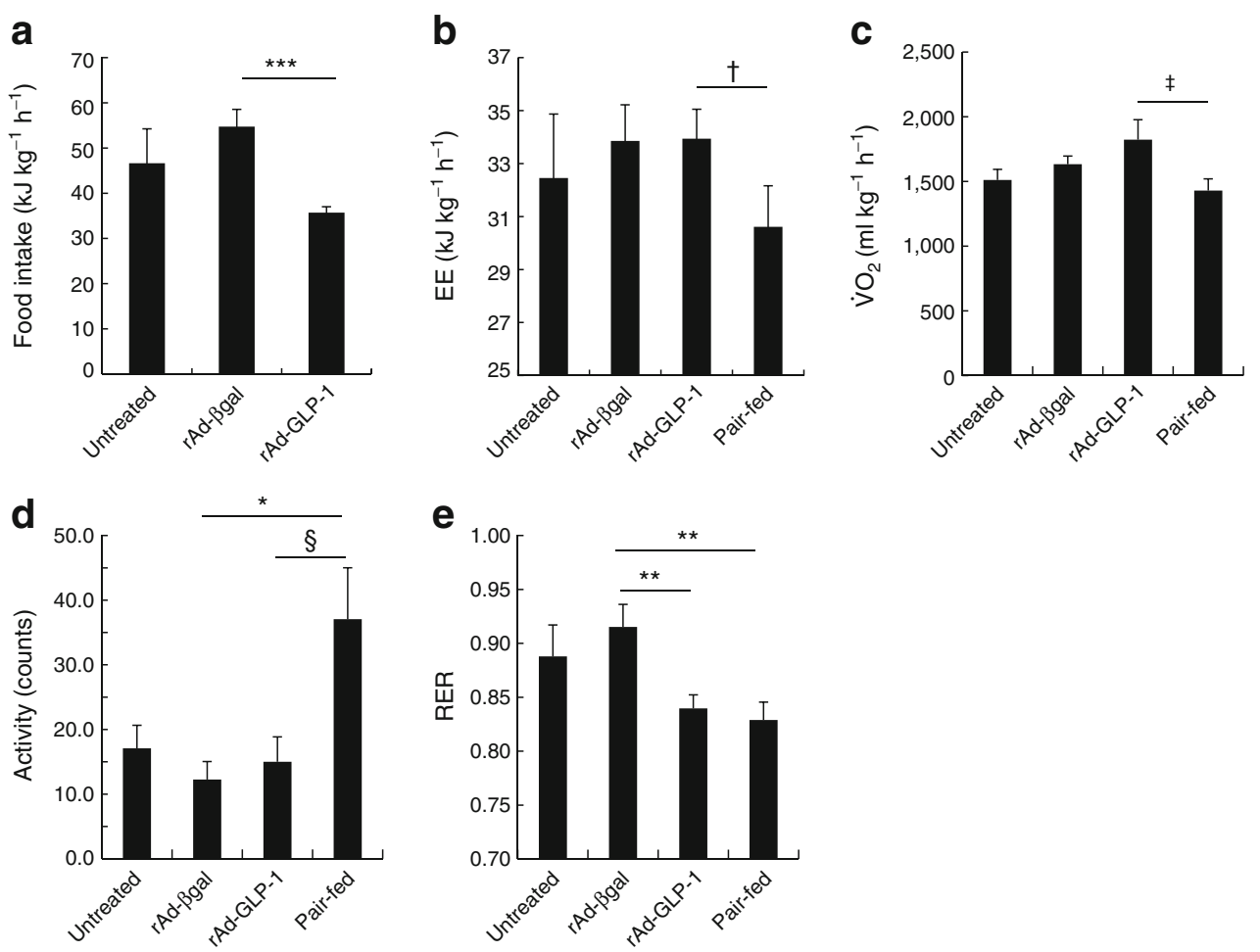

balance could affect fat mass and adipocyte size [45]. A reduction of food intake in animals is usually accompanied by a reduction of energy use [46]. However, we did not observe any differences in energy expenditure in rAd-GLP1 -treated mice compared with rAd- $\beta$ gal-treated mice, despite a significant decrease in food intake in the former. In addition, we observed a tendency for rAd-GLP-1-treated $o b$ / $o b$ mice to exhibit higher energy expenditure than the pairfed group, which had the same amount of food intake as the rAd-GLP-1-treated group. Locomotor activity was significantly increased in the pair-fed group, perhaps as a result of food searching activity. This increased activity and possibly energy expenditure may have affected body weight, adipose tissue mass or IL-6 levels. The respiratory exchange ratio was significantly decreased in the rAd-GLP-1-treated and pair-fed groups compared with the rAd- $\beta$ gal-treated group, suggesting that these groups used more fat than carbohydrate. We also found that fat oxidation was increased in exendin-4treated $\mathrm{C} 2 \mathrm{C} 12$ cells compared with untreated cells (unpublished data; Y.-S. Lee, J.-S. Choung, H.-S. Jun). These results suggest that increases in fat oxidation and energy expenditure may partly contribute to the reduction of fat mass in rAd-GLP1 -treated mice.

In conclusion, our studies show that GLP-1 attenuates macrophage infiltration and production of inflammatory cytokines in the adipose tissue of $o b / o b$ mice. GLP-1 directly inhibits inflammatory signalling pathways, such as NF- $\mathrm{KB}$, in adipocytes and ATM, resulting in a decrease of inflammatory cytokine levels in adipose tissue. In addition, GLP-1 might increase fat oxidation and energy expenditure, which would contribute to a reduction of fat mass with subsequent improvement of insulin sensitivity. All these actions of GLP-1 may therefore have a beneficial effect on insulin sensitivity in rAdGLP-1-treated $o b / o b$ mice.

Acknowledgements We thank A. Kyle (University of Calgary) for editorial assistance, M. Mamura and Y.-J. Kang (Lee Gil Ya Cancer and Diabetes Institute) for FACS analysis, and the Center of Animal Care and Use (Lee Gil Ya Cancer and Diabetes Institute) for provision of animal care.

Funding This work was supported by a grant from the Ministry of Korea Science and Engineering Foundation (20090071938), a grant from National Research Foundation of Korea (NRF: no. 20090079342) and a grant from the Innovative Research Institute for Cell Therapy (A062260).

Duality of interest The authors declare that there is no duality of interest associated with this manuscript.

Contribution statement YSL contributed to the conception and design of the study, researched data and wrote the manuscript. MSP, JSC, SSK, HHO and SYH researched data and revised the manuscript. CSC, Y Kang and Y Kim participated in the analysis and interpretation of data, and in the revision of the manuscript. HSJ contributed to conception and design of the study, and wrote, reviewed and edited the manuscript. All authors approved the version to be published. 


\section{References}

1. Bastard JP, Maachi M, Lagathu C et al (2006) Recent advances in the relationship between obesity, inflammation, and insulin resistance. Eur Cytokine Netw 17:4-12

2. Aldhahi W, Hamdy O (2003) Adipokines, inflammation, and the endothelium in diabetes. Curr Diab Rep 3:293-298

3. Lumeng CN, Deyoung SM, Saltiel AR (2007) Macrophages block insulin action in adipocytes by altering expression of signaling and glucose transport proteins. Am J Physiol Endocrinol Metab 292: E166-E174

4. Arkan MC, Hevener AL, Greten FR et al (2005) IKK-beta links inflammation to obesity-induced insulin resistance. Nat Med 11:191-198

5. Kanda H, Tateya S, Tamori Y et al (2006) MCP-1 contributes to macrophage infiltration into adipose tissue, insulin resistance, and hepatic steatosis in obesity. J Clin Invest 116:1494-1505

6. Weisberg SP, Hunter D, Huber R et al (2006) CCR2 modulates inflammatory and metabolic effects of high-fat feeding. J Clin Invest 116:115-124

7. Winer S, Chan Y, Paltser G et al (2009) Normalization of obesityassociated insulin resistance through immunotherapy. Nat Med 15:921-929

8. Kieffer TJ, Habener JF (1999) The glucagon-like peptides. Endocr Rev 20:876-913

9. Drucker DJ (2006) The biology of incretin hormones. Cell Metab 3:153-165

10. Lee YS, Shin S, Shigihara T et al (2007) Glucagon-like peptide-1 gene therapy in obese diabetic mice results in long-term cure of diabetes by improving insulin sensitivity and reducing hepatic gluconeogenesis. Diabetes 56:1671-1679

11. Zander M, Madsbad S, Madsen JL, Holst JJ (2002) Effect of 6-week course of glucagon-like peptide 1 on glycaemic control, insulin sensitivity, and beta-cell function in type 2 diabetes: a parallel-group study. Lancet 359:824-830

12. Parlevliet ET, de Leeuw van Weenen JE, Romijn JA, Pijl H (2010) GLP-1 treatment reduces endogenous insulin resistance via activation of central GLP-1 receptors in mice fed a high-fat diet. Am J Physiol Endocrinol Metab 299:E318-E324

13. Idris I, Patiag D, Gray S, Donnelly R (2002) Exendin-4 increases insulin sensitivity via a PI-3-kinase-dependent mechanism: contrasting effects of GLP-1. Biochem Pharmacol 63:993-996

14. Gao H, Wang X, Zhang $Z$ et al (2007) GLP-1 amplifies insulin signaling by up-regulation of IRbeta, IRS-1 and Glut4 in 3T3-L1 adipocytes. Endocrine 32:90-95

15. le Kim Chung T, Hosaka T, Yoshida M et al (2009) Exendin-4, a GLP-1 receptor agonist, directly induces adiponectin expression through protein kinase A pathway and prevents inflammatory adipokine expression. Biochem Biophys Res Commun 390:613618

16. Rotter V, Nagaev I, Smith U (2003) Interleukin-6 (IL-6) induces insulin resistance in 3T3-L1 adipocytes and is, like IL-8 and tumor necrosis factor-alpha, overexpressed in human fat cells from insulin-resistant subjects. J Biol Chem 278:45777-45784

17. Ajuwon KM, Spurlock ME (2005) Palmitate activates the NFkappaB transcription factor and induces IL-6 and TNFalpha expression in 3T3-L1 adipocytes. J Nutr 135:1841-1846

18. Wadman IA, Osada H, Grutz GG et al (1997) The LIM-only protein Lmo2 is a bridging molecule assembling an erythroid, DNA-binding complex which includes the TAL1, E47, GATA-1 and Ldb1/NLI proteins. EMBO J 16:3145-3157

19. Nguyen MT, Favelyukis S, Nguyen AK et al (2007) A subpopulation of macrophages infiltrates hypertrophic adipose tissue and is activated by free fatty acids via Toll-like receptors 2 and 4 and JNK-dependent pathways. J Biol Chem 282:35279-35292
20. Filipov NM, Seegal RF, Lawrence DA (2005) Manganese potentiates in vitro production of proinflammatory cytokines and nitric oxide by microglia through a nuclear factor kappa B-dependent mechanism. Toxicol Sci 84:139-148

21. Edelman DA, Jiang Y, Tyburski JG, Wilson RF, Steffes CP (2007) Cytokine production in lipopolysaccharide-exposed rat lung pericytes. J Trauma 62:89-93

22. Rodriguez-Calvo R, Serrano L, Coll T et al (2008) Activation of peroxisome proliferator-activated receptor beta/delta inhibits lipopolysaccharide-induced cytokine production in adipocytes by lowering nuclear factor-kappaB activity via extracellular signalrelated kinase 1/2. Diabetes 57:2149-2157

23. Ozes ON, Mayo LD, Gustin JA, Pfeffer SR, Pfeffer LM, Donner DB (1999) NF-kappaB activation by tumour necrosis factor requires the Akt serine-threonine kinase. Nature 401:82-85

24. Nam KN, Son MS, Park JH, Lee EH (2008) Shikonins attenuate microglial inflammatory responses by inhibition of ERK, Akt, and NF-kappaB: neuroprotective implications. Neuropharmacology 55:819-825

25. Cai D, Yuan M, Frantz DF et al (2005) Local and systemic insulin resistance resulting from hepatic activation of IKK-beta and NFkappaB. Nat Med 11:183-190

26. Kim JK, Kim YJ, Fillmore JJ et al (2001) Prevention of fatinduced insulin resistance by salicylate. J Clin Invest 108:437-446

27. Kiefer FW, Zeyda M, Gollinger K et al (2010) Neutralization of osteopontin inhibits obesity-induced inflammation and insulin resistance. Diabetes 59:935-946

28. Sandeep S, Gokulakrishnan K, Velmurugan K, Deepa M, Mohan V (2010) Visceral \& subcutaneous abdominal fat in relation to insulin resistance \& metabolic syndrome in non-diabetic south Indians. Indian J Med Res 131:629-635

29. Usui C, Asaka M, Kawano H et al (2010) Visceral fat is a strong predictor of insulin resistance regardless of cardiorespiratory fitness in non-diabetic people. J Nutr Sci Vitaminol (Tokyo) 56:109 116

30. Valverde I, Merida E, Delgado E, Trapote MA, VillanuevaPenacarrillo ML (1993) Presence and characterization of glucagon-like peptide-1(7-36) amide receptors in solubilized membranes of rat adipose tissue. Endocrinology 132:75-79

31. Sancho V, Trigo MV, Gonzalez N, Valverde I, Malaisse WJ, Villanueva-Penacarrillo ML (2005) Effects of glucagon-like peptide-1 and exendins on kinase activity, glucose transport and lipid metabolism in adipocytes from normal and type-2 diabetic rats. J Mol Endocrinol 35:27-38

32. Pandey AK, Munjal N, Datta M (2010) Gene expression profiling and network analysis reveals lipid and steroid metabolism to be the most favored by TNFalpha in HepG2 cells. PLoS One 5:e9063

33. Girard J, Perdereau D, Foufelle F, Prip-Buus C, Ferre P (1994) Regulation of lipogenic enzyme gene expression by nutrients and hormones. FASEB J 8:36-42

34. Foufelle F, Girard J, Ferre P (1996) Regulation of lipogenic enzyme expression by glucose in liver and adipose tissue: a review of the potential cellular and molecular mechanisms. Adv Enzyme Regul 36:199-226

35. Samuvel DJ, Sundararaj KP, Li Y, Lopes-Virella MF, Huang Y (2010) Adipocyte-mononuclear cell interaction, Toll-like receptor 4 activation, and high glucose synergistically up-regulate osteopontin expression via an interleukin 6-mediated mechanism. J Biol Chem 285:3916-3927

36. Xie L, Ortega MT, Mora S, Chapes SK (2010) Interactive changes between macrophages and adipocytes. Clin Vaccine Immunol 17:651-659

37. Patsouris D, Li PP, Thapar D, Chapman J, Olefsky JM, Neels JG (2008) Ablation of CD11c-positive cells normalizes insulin sensitivity in obese insulin resistant animals. Cell Metab 8:301-309 
38. Fuentes L, Roszer T, Ricote M (2010) Inflammatory mediators and insulin resistance in obesity: role of nuclear receptor signaling in macrophages. Mediators Inflamm 2010:219583

39. Singh R, Wang Y, Xiang Y, Tanaka KE, Gaarde WA, Czaja MJ (2009) Differential effects of JNK1 and JNK2 inhibition on murine steatohepatitis and insulin resistance. Hepatology 49:8796

40. Wunderlich FT, Luedde T, Singer S et al (2008) Hepatic NF-kappa $\mathrm{B}$ essential modulator deficiency prevents obesity-induced insulin resistance but synergizes with high-fat feeding in tumorigenesis. Proc Natl Acad Sci U S A 105:1297-1302

41. Schmidt C, Hocherl K, Kurt B, Bucher M (2008) Role of nuclear factor-kappaB-dependent induction of cytokines in the regulation of vasopressin V1A-receptors during cecal ligation and punctureinduced circulatory failure. Crit Care Med 36:2363-2372
42. De Souza CT, Araujo EP, Bordin S et al (2005) Consumption of a fatrich diet activates a proinflammatory response and induces insulin resistance in the hypothalamus. Endocrinology 146:4192-4199

43. Kodera R, Shikata K, Kataoka HU et al (2011) Glucagon-like peptide-1 receptor agonist ameliorates renal injury through its anti-inflammatory action without lowering blood glucose level in a rat model of type 1 diabetes. Diabetologia 54:965-978

44. Shiraki A, Oyama J, Komoda H et al (2012) The glucagon-like peptide 1 analog liraglutide reduces TNF-alpha-induced oxidative stress and inflammation in endothelial cells. Atherosclerosis 221:375-382

45. Redinger RN (2009) Fat storage and the biology of energy expenditure. Transl Res 154:52-60

46. MacDonald IA, Webber J (1995) Feeding, fasting and starvation: factors affecting fuel utilization. Proc Nutr Soc 54:267-274 